Please do not remove this page

RMIT

UNIVERSITY

\title{
Work-family conflict in construction: Case for a finer-grained analysis
}

Lingard, Helen; Francis, Valerie; Turner, Michelle

https://researchrepository.rmit.edu.au/esploro/outputs/9921857655001341/filesAndLinks?institution=61RMIT_INST\&index=null

Lingard, H., Francis, V., \& Turner, M. (2010). Work-family conflict in construction: Case for a finer-grained analysis. Journal of Construction Engineering and Management, 136(11), 1196-1206.

https://doi.org/10.1061/(ASCE)CO.1943-7862.0000229

Document Version: Accepted Manuscript

Published Version: https://doi.org/10.1061/(ASCE)CO.1943-7862.0000229

Repository homepage: https://researchrepository.rmit.edu.au

(c) ASCE

Downloaded On 2023/04/26 22:51:02 +1000

Please do not remove this page 
Thank you for downloading this document from the RMIT Research Repository.

The RMIT Research Repository is an open access database showcasing the research outputs of RMIT University researchers.

RMIT Research Repository: http://researchbank.rmit.edu.au/

\section{Citation:}

Lingard, H, Francis, V and Turner, M 2010, 'Work-family conflict in construction: Case for a finer-grained analysis', Journal of Construction Engineering and Management, vol. 136, no. 11, pp. 1196-1206.

See this record in the RMIT Research Repository at:

https://researchbank.rmit.edu.au/view/rmit:5951

Version: Accepted Manuscript

Copyright Statement: (c) ASCE

Link to Published Version:

10.1061/(ASCE)CO.1943-7862.0000229 


\title{
Work-family conflict in construction: The case for a finer grained analysis
}

\begin{abstract}
A multi-dimensional work-family conflict (WFC) scale was tested using a sample of 169 workers in the Australian construction industry. The construction sample showed higher mean score for time-, strain- and behaviour-based work-interference with family (WIF) than scores reported in international studies that have used the multi-dimensional scale. Waged construction workers, who work on site in direct construction activity, reported higher levels of time- and strain-based WIF than salaried workers, who work predominantly in office-based roles. Mean levels family-interference with work (FIW) in the construction sample were generally comparable to levels reported in previous research. A principal components analysis revealed four clear dimensions of WFC. These dimensions were significantly correlated with other variables of theoretical relevance indicating acceptable criterion validity. The experience of WIF varied by workers' employment situation, sex and work location, while the experience of FIW varied by workers' age. The results suggest that the use of global measures of WFC might mask important differences in construction workers' experiences at the work-family interface.
\end{abstract}

\section{Keywords}

Work-family conflict, time-based, behaviour-based, strain-based conflict. Family interference with work, work interference with family

\section{Introduction}

\section{Work-family conflict}

Work-family conflict (WFC) has been defined as "a form of interrole conflict in which role pressures from the work and family domains are mutually incompatible in some respect” (Greenhaus \& Beutell, 1985, p. 77). WFC has been consistently linked to negative outcomes for individuals, families and employing organisations. For example, work interference with family has been associated with job dissatisfaction, life dissatisfaction, intention to turnover, general well-being, psychological strain, psychiatric disorders, substance abuse and problem drinking (Netemeyer, Boles \& McMurrian, 1996; Boyar, Maertz, Pearson \& Keough, 2003; O'Driscoll, Poelmans, Kalliath, Allen, Cooper, \& Sanchez, 2003; Grant-Vallone \& Donaldson, 2001; Hammer, Saksvik, Nytrø, Torvatn \& Bayazit 2004; Frone, 2000; Grzywacz \& Marks, 2000; Allen, Herts, Bruck \& Sutton, 2000).

Research in the Australian construction industry revealed that project-based construction workers experience high levels of WFC, which is predicted by excessive job demands, including long and irregular work hours (Lingard \& Francis, 2004). The Australian research also revealed that WFC acts as the linking mechanism between work schedule demands and employee burnout (Lingard \& Francis 2005) and that certain job characteristics, including supervisor support, moderate the relationship between WFC on employee burnout (Lingard \& Francis, 2006).

Researchers distinguish between two directions of WFC: work interfering with family life (WIF), and family interfering with work life (FIW) (Mesmer-Magnus \& Viswesvaran, 2005). These two directions of WFC have been found to be related but distinct concepts with unique and different sources and outcomes in the work and family environments (Brough, O’Driscoll \& Kalliath 2005). Frone, Yardley \& Markel (1997) tested a model of the work-family interface in which WFC was theoretically positioned as a key variable, linking experiences in the work domain with experiences in the family domain. Their results suggest that work stressors adversely affect family role performance (and vice versa) through employees' subjective experience of WFC. Frone et al. (1997) also report that predictors of both directions of WFC are domain-specific, i.e. stressors in the work environment (work overload and work distress) predict WIF, while stressors in the family domain (family distress and parental overload) predict FIW. Frone et al. (1997) also suggested home domain-specific outcomes, for FIW and WIF. Research by Lingard \& Francis (2007) in the Australian construction industry supports the theory that WFC is a linking mechanism between work and family domains, but suggests different domain specific outcomes to those suggested by Frone et al. (1997). Whereas WIF was negatively associated with quality of family relationships (a family domain outcome), it was also negatively correlated with job satisfaction 
and organizational commitment and positively correlated with turnover intention (work domain outcomes). Lingard and Francis (2007) also reveal that, for workers in the Australian construction industry, family life is more susceptible to interference from work than work is susceptible to interference from family life.

\section{The multi-dimensional nature of work-family conflict}

Greenhaus and Beutell (1985) suggested that WFC can take three forms, as follows:

(1) Time-based conflict, which occurs when time spent on activities in one role prohibits the fulfillment of responsibilities in another role;

(2) Behaviour-based conflict, which occurs when behaviour in one role cannot be adjusted to be compatible with behaviour patterns in another role; and

(3) Strain-based conflict, which occurs when pressures from one role interfere with fulfilling the requirements of another role.

Much previous research has ignored the multidimensionality of WFC (Bruck, Allen \& Spector, 2002; Ford, Heinen \& Langkamar, 2007). In particular, behaviour-based conflict is often omitted in global measures of WFC (Dierdorff \& Ellington, 2008). For example, one of the most frequently used measures for WFC, a scale developed by Netemeyer, Boles and McMurrian (1996), contains items that describe time- and strain-based WIF and FIW but does not include items that adequately capture the concept of behaviour-based WFC. This is a problem for both theoretical and practical reasons. Researchers who have used multi-dimensional measures of WFC have reported different antecedents and outcomes associated with time-, strain- and behaviour-based WFC (Carlson, Kacmar \& Williams, 2000). Arguably, the use of global measures of WFC has prevented researchers from examining how the different manifestations of WFC vary in terms of their relationship with outcomes of interest. There is emerging evidence to indicate considerable variation. For example, Bruck et al. (2002) report that behaviour-based WFC explains variability in workers' job satisfaction over and above that explained by time and strain-based conflict. Indeed, when the three dimensions of conflict were considered together, behaviour-based conflict was the only dimension that significantly predicted job satisfaction. Similarly, Janzen, Muhajarine and Kelly (2007) report strain-based, but not time-based, WIF to be related to psychological distress in a sample of Canadian police officers.

A failure to distinguish between different dimensions of WFC is likely to mask important differences that could help researchers to better understand the process by which WFC impacts upon workers at the work-family interface. Further, the use of global WFC measures can obscure subtle differences in the work-family experiences of different worker groups. For example, Madsen (2006) found that the number of children an employee has is more strongly correlated with time-based WFC than the number of hours they work, and men report significantly higher levels of behaviour-based WFC than women. Carlson, Derr \& Wadsworth (2003) also report individual differences in career orientation are associated with different patterns of WFC, highlighting the importance of adopting a finer-grained analysis of the concept than permitted by unidimensional measures.

\section{Aims}

The aims of this research were to test a multi-dimensional model of WFC conflict in a non-random Australian construction industry sample and investigate the correlates of three dimensions of WFC advanced by Greenhaus \& Beutell (1989) and operationalised by Carlson et al. (2000). Specifically the research sought to answer the following questions:

(1) To what extent do construction workers distinguish between different dimensions of WFC, i.e. strainbased, time-based and behaviour-based?

(2) Are the three dimensions of WFC differentially related to theoretically relevant antecedents and/or outcomes?

(3) Are the dimensions of WFC experienced differently by construction workers in different demographic groups, e.g. male and female workers, workers in different family arrangements and waged and salaried workers? 


\section{Methods}

\section{Data collection}

Data collection was performed using the 'TurningPoint' automated response system with 'KeyPad' hand held devices. The advantages of this system include the completeness of data and minimisation of human error in data entry (de Quiros, Lopez, Aranda-Mena, \& Edwards, 2008). One hundred and sixty nine participants completed the survey. All participants were working on a large civil construction project which was utilising an alliance contract. One defining feature of alliance contracts is that participants are selected on the basis of their capability, approaches and systems as well as their commitment, chemistry and the likelihood of them delivering outstanding results (Hutchinson and Gallagher 2003).Unlike traditional selection processes, in project alliancing, participants are selected before a price is considered. Typically, project alliance objectives extend beyond the traditional emphasis on price, to include the ability to innovate and manage relationships within and between alliance participants.

\section{Demographic information}

Participants were asked to indicate their sex, age and the number of children they have. To distinguish between the presence of dependent and non-dependent children, participants were asked to indicate how many children they have under the age of 18 and aged 18 years or over. Participants were also asked to indicate how many hours on average they work each week.

Work-family conflict was measured using a scale developed by Carlson, Kacmar \& Williams (2000). This scale comprises six subscales. Each direction of WFC (i.e., WIF and FIW) is nested within three dimensions of conflict (i.e., time-based, strain-based and behaviour-based). Each subscale comprises three items. Example items are: (i) "My work keeps me from my family activity more than I would like" (time-based WIF); (ii) "The times I spend on family responsibilities often interferes with my work responsibilities" (time-based FIW); (iii) "I am often so emotionally drained when I get home from work that it prevents me from contributing to my family" (strain-based WIF); (iv) 'Because I am often stressed from family responsibilities I have a hard time concentrating on my work" (strain-based FIW); (v) "Behaviour that is necessary and effective for me at work would be counterproductive at home" (behaviour-based WIF); and (vi) "The behaviours that work for me at home do not seem to be effective at work" (behaviour-based FIW). Responses were provided on a five point scale ranging from strongly disagree (1) to strongly agree (5). Owing to the fact that the sample was heterogeneous, one item was removed from the dataset prior to analysis. The wording of this item (The behaviours I perform that make me effective at work do not help me to be a better parent and spouse) suggested that respondents were partnered with children, which was not the case in the construction sample. Thus, only two behaviour-based WIF items were included in the data analysis.

Other variables (covariates) that have been theoretically or empirically linked to WFC were also measured by the survey. The covariates that were measured, the scale by which they were measured and example items taken from this scale are presented in Table 1.

Table 1: Covariates of WFC and the measurement scales used.

\begin{tabular}{|l|l|l|l|l|}
\hline Covariate & \multicolumn{1}{|c|}{ Scale } & $\begin{array}{l}\text { No. of } \\
\text { items }\end{array}$ & \multicolumn{1}{c|}{ Example items } & Method \\
\hline $\begin{array}{l}\text { Time } \\
\text { adequacy }\end{array}$ & $\begin{array}{l}\text { Van Horn, Bellis \& } \\
\text { Snyder, as cited in } \\
\text { Moen, Kelly \& Huang } \\
(2008)\end{array}$ & 12 & $\begin{array}{l}\text { "please indicate the frequency with which } \\
\text { there is enough time for you to keep in shape" } \\
\text { "please indicate the frequency with which } \\
\text { there is enough time for you to prepare or eat } \\
\text { health meals." }\end{array}$ & $\begin{array}{l}\text { Seven point scale ranging from } \\
\text { one (not at all) to seven (all the } \\
\text { time). }\end{array}$ \\
\hline Control & $\begin{array}{l}\text { Thomas and Ganster } \\
(1995) .\end{array}$ & 7 & $\begin{array}{l}\text { "how much choice do you have over when you } \\
\text { begin and end each workday or each } \\
\text { workweek?" }\end{array}$ & $\begin{array}{l}\text { Five point scale ranging from } \\
\text { one (very little) to five (very } \\
\text { great). }\end{array}$ \\
\hline
\end{tabular}




\begin{tabular}{|c|c|c|c|c|}
\hline & & & $\begin{array}{l}\text { "to what extent can you choose to do some of } \\
\text { your work at home instead of your usual place } \\
\text { of employment?" }\end{array}$ & \\
\hline Flexibility & $\begin{array}{l}\text { Hill, Hawkins, Ferris \& } \\
\text { Weitzman (2001). }\end{array}$ & 2 & $\begin{array}{l}\text { "how much flexibility do you have in } \\
\text { scheduling when you do your work" } \\
\text { "I have sufficient flexibility in my job to } \\
\text { maintain adequate work, personal and family } \\
\text { life balance." }\end{array}$ & $\begin{array}{l}\text { Five point scale ranging from } \\
\text { ranging from one (strongly } \\
\text { disagree) to five (strongly } \\
\text { agree). }\end{array}$ \\
\hline $\begin{array}{l}\text { Supervisor } \\
\text { support }\end{array}$ & $\begin{array}{l}\text { Items drawn from } \\
\text { Lambert, (2000) and } \\
\text { Thomas and Ganster, } \\
\text { (1995) }\end{array}$ & 4 & $\begin{array}{l}\text { "my immediate supervisor is concerned about } \\
\text { me as a person" } \\
\text { "my immediate supervisor would switch } \\
\text { schedules (hours, overtime hours, vacation) to } \\
\text { accommodate my family responsibilities" }\end{array}$ & $\begin{array}{l}\text { Five point scale ranging from } \\
\text { one (not at all) to five (all of } \\
\text { the time). }\end{array}$ \\
\hline $\begin{array}{l}\text { Work } \\
\text { schedule fit }\end{array}$ & $\begin{array}{l}\text { Barnett \& Brennan, as } \\
\text { cited in Moen, Kelly \& } \\
\text { Huang (2008) }\end{array}$ & 2 & $\begin{array}{l}\text { "taking into account your current work hours } \\
\text { and schedule, how well is your work } \\
\text { arrangement working for you?" } \\
\text { "taking into account your current work hours } \\
\text { and schedule, how well is your work } \\
\text { arrangement working for your family or } \\
\text { personal life?" }\end{array}$ & $\begin{array}{l}\text { Seven point scale ranging from } \\
\text { one (extremely poorly) to } \\
\text { seven (extremely well). }\end{array}$ \\
\hline
\end{tabular}

In addition, the concept of work-family enrichment was measured using six items drawn from the National Survey of Midlife Development in the United States, as cited in Grzywacz \& Marks (2000). This scale was used by Wayne, Musisca \& Fleeson (2004) and Innstrand, Langballe, Espnes, Falkum, \& Aasland (2008) to measure work-family facilitation and was used by Grzyzwacz \& Butler (2005) as a measure of positive spillover between work and family, facilitation, illustrating the way in which these terms have been used interchangeably in previous research. However, the items imply a transfer of energy or behaviours that also improve performance in the other role (Hanson, Hammer \& Colton, 2006). Thus, we refer to this as work-family enrichment in accordance with the conceptual definitions of positive work-family interaction provided by Carlson et al. (2006) and Wayne et al. (2007). Example items include "The things I do at work help me deal with personal and practical issues at home" and "Talking with someone at home helps me deal with problems at work." Participants were asked to indicate how often they experienced these circumstances in the past year. The items were scored on a five point scale ranging from one (never) to five (all of the time).

\section{Data analysis}

Mean scores for the six dimensions of WFC (i.e., time-, strain- and behaviour-based WIF and FIW) were calculated and compared against mean scores for these six dimensions reported in previous studies. Data collected using the multi-dimensional WFC scale was analysed using a principal components analysis (PCA) with varimax rotation. PCA assumes that underlying dimensions or factors can be used to explain complex phenomena. The goal of PCA is to identify the not-directly-observable factors based on a set of observable or measurable indicators. The first step in factor analysis is to produce a correlation matrix for all variables. Variables that do not appear to be related to other variables can be identified from this matrix. The number of factors necessary to represent the data and the method for calculating them must then be determined. In PCA linear combinations of variables are formed. The first principal component is that which accounts for the largest amount of variance in the sample, the second principal component is that which accounts for the next largest amount of variance and is uncorrelated with the first and so on. Coefficients (factor loadings), that relate variables to the identified factors are calculated. The factor model can then be rotated to transform the factors and make them more interpretable. The most commonly used method for rotation is varimax rotation which seeks to minimise the number of variables that have high loadings on a factor thus permitting the factors to be differentiated from one another. Following rotation, scores for each factor can be computed for each case in a sample. These scores can then be used in further data analysis. Following the PCA, the criterion validity of the emerging WFC dimensions was determined by examining the bi-variate Pearson Product Moment correlations between the scores derived for each of the WFC factors and other theoretically relevant work and family 
variables. Finally, the WFC levels of different categories of respondent were compared using paired samples ttests and one way analyses of variance (ANOVAs).

\section{Results}

\section{The sample}

One hundred and sixty nine (169) surveys were completed. Table 2 shows the characteristics of the sample. The majority of respondents was male $(n=149,88.2 \%)$. Twenty respondents $(11.8 \%)$ were female. The sample was mixed in terms of family status and age. However, older workers were not as well represented as younger workers. Forty seven respondents $(27.8 \%)$ were aged 30 or younger. Fifty one respondents $(30.2 \%)$ were between the ages of 31 and 40, while 48 respondents (28.4\%) were between 41 and 50. Twenty two respondents $(13.1 \%)$ were 51 or older. One hundred and one respondents $(59.8 \%)$ indicated that they were parents, while 68 $(40.2 \%)$ were child-free. The majority of respondents $(n=128,75.7 \%)$ were partnered and $41(24.3 \%)$ were single. The modal number of children under the age of 18 was two, with 37 respondents $(21.9 \%)$ indicating they have two children under the age of 18. Another 22 respondents (33\%) indicated they have one dependent child. The sample was split fairly evenly between waged and salaried workers. Eighty six respondents (50.9\%) indicated they were waged and $83(40.1 \%)$ were salaried workers. Ninety one respondents $(53.8 \%)$ indicated they work on site, and a further $67(39.6 \%)$ indicated they are based in the site office. The majority of participants $(n=129,76.3 \%)$ worked long hours, i.e. in excess of 45 hours per week. Only 10 respondents $(5.9 \%)$ indicated they worked, on average, 40 hours a week or less.

Table 2: Demographic characteristics of the sample

\begin{tabular}{|c|c|c|c|c|c|}
\hline & $\mathbf{N}$ & $\%$ & & $\mathbf{N}$ & $\%$ \\
\hline Sex & & & No. of children =>18 & & \\
\hline Male & 149 & 88.2 & 1 & 22 & 13.0 \\
\hline \multirow[t]{2}{*}{ Female } & 20 & 11.8 & 2 & 14 & 8.3 \\
\hline & & & 3 & 9 & 5.3 \\
\hline Age & & & 4 & 3 & 1.8 \\
\hline 30 and under & 47 & 27.8 & $>4$ & 1 & .6 \\
\hline $31-40$ & 51 & 30.2 & N/A & 117 & 69.2 \\
\hline $41-50$ & 48 & 28.4 & Missing data & 3 & 1.8 \\
\hline $51-60$ & 18 & 10.7 & & & \\
\hline Over 60 & 4 & 2.4 & No. of children $<18$ & & \\
\hline \multirow[t]{2}{*}{ Missing data } & 1 & 0.6 & 1 & 22 & 13.0 \\
\hline & & & 2 & 37 & 21.9 \\
\hline Children & & & 3 & & \\
\hline Yes & 101 & 59.8 & 4 & 4 & 2.4 \\
\hline \multirow[t]{2}{*}{ No } & 68 & 40.2 & $>4$ & 2 & 1.2 \\
\hline & & & N/A & 91 & 53.8 \\
\hline \multicolumn{2}{|c|}{ Relationship status } & & Missing data & 1 & 0.6 \\
\hline Partnered & 128 & 75.7 & & & \\
\hline \multirow[t]{2}{*}{ Single } & 41 & 24.3 & Hours worked per week & & \\
\hline & & & $<35$ & 2 & 1.2 \\
\hline Type of pay & & & $35-40$ & 8 & 4.7 \\
\hline Waged & 86 & 50.9 & $41-45$ & 29 & 17.2 \\
\hline \multirow[t]{2}{*}{ Salaried } & 83 & 49.1 & $46-50$ & 29 & 17.2 \\
\hline & & & $51-55$ & 46 & 27.2 \\
\hline Work location & & & $56-60$ & 32 & 18.9 \\
\hline On site & 91 & 53.8 & $61-65$ & 12 & 7.1 \\
\hline Site Office & 67 & 39.6 & $>65$ & 10 & 5.9 \\
\hline Other & 11 & 6.5 & Missing data & 1 & 0.6 \\
\hline
\end{tabular}


WFC scores

Table 3 shows the mean WFC scores for each of the six types of WFC identified by Carlson et al. (2000) for the present (i.e., construction) sample compared with scores from previous research in which WFC was measured using the same scale. The construction sample showed the highest mean score for time-, strain- and behaviourbased WIF of any of the studies reported. Furthermore, waged construction workers, who work exclusively on site in direct construction activity, reported higher levels of time- and strain-based WIF than salaried workers, who work predominantly in office-based roles. ${ }^{1}$ Mean levels of time-, strain- and behaviour-based FIW reported by the construction sample were generally comparable to mean levels of FIW reported in previous research.

\footnotetext{
${ }^{1}$ In the Australian construction industry workers can be classed as waged or salaried, based upon their employment terms and conditions. Salaried workers are managerial, administrative or professional workers who work for the majority of their time in an office environment. Waged workers are blue collar workers who work for the majority of their time on site engaged directly in construction work. These two groups are mutually exclusive.
} 
Table 3: Comparison of WFC scores with other studies

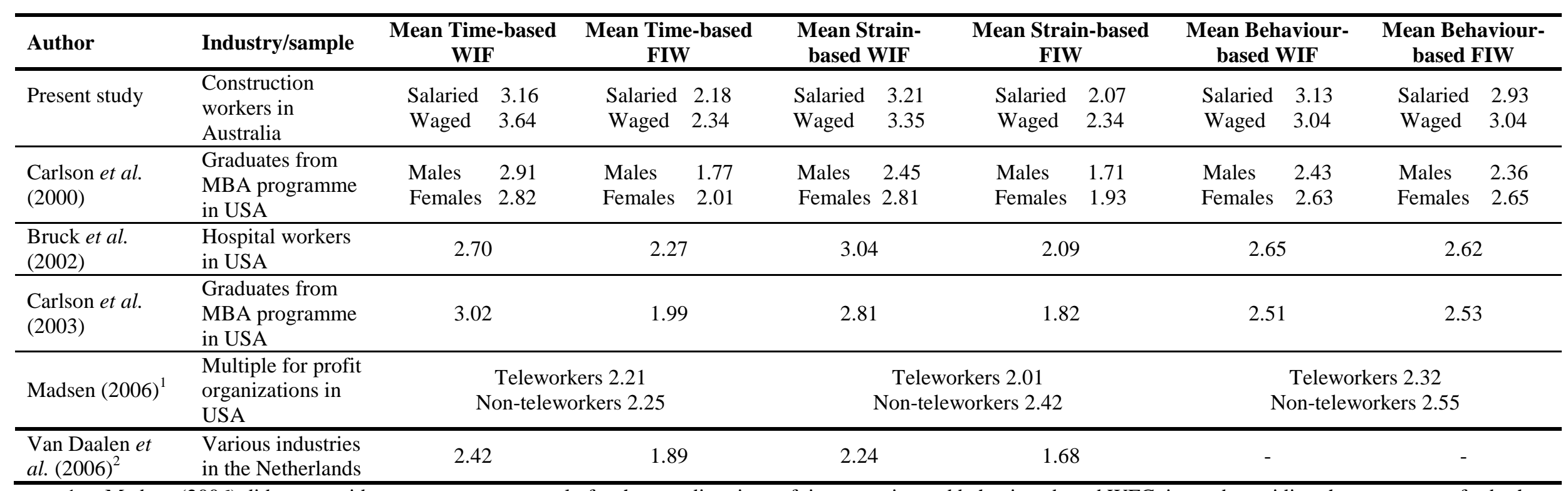

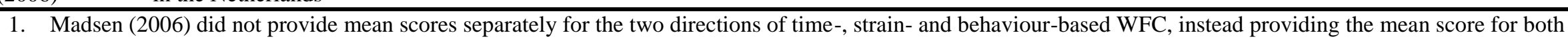
directions of the three WFC dimensions for teleworkers and non-teleworkers.

2. Van Daalen et al. (2006) reported only time- and strain-based WFC. 


\section{Principal components analysis}

The PCA did not yield a six factor structure, representing the six dimensions of time- strain- and behaviour based WIF and FIW suggested by Carlson et al. (2000). Indeed, inspection of the scree plot suggested a four factor solution, which was supported by an unconstrained PCA with varimax rotation. The rotated components matrix is shown in Table 4, which also shows the subscale to which Carlson et al. (2000) suggest each item should belong (in italics). Notwithstanding the failure to replicate Carlson et al.'s (2000) six factor structure, an examination of the items loading on each of the factors yielded by the PCA indicates that the Australian construction workers in this sample do discriminate between the type and direction of WFC. Time- and strainbased WIF items loaded together on the first factor (explaining most of the variance). Strain-based family interference with work items loaded clearly and consistently on the second factor. All of the behaviour-based WFC (i.e. those describing behaviour-based WIF and FIW) loaded on the third factor, while time-based FIW items clearly loaded on the fourth factor. All item loadings were in excess of .50 and there was no doubleloading of items. The four factor solution explained $60.57 \%$ of the variance and the alpha coefficients were .870 for Factor 1, .819 for Factor 2, .598 for Factor 3 and .728 for Factor 4.

\section{Table 4: Rotated component matrix for the work-family conflict items}

\begin{tabular}{|c|c|c|c|c|c|}
\hline & \multicolumn{5}{|c|}{ Principal Component } \\
\hline & $\begin{array}{l}\text { Theoretical } \\
\text { component }\end{array}$ & 1 & 2 & 3 & 4 \\
\hline $\begin{array}{l}\text { When I get home from work I am often too frazzled to } \\
\text { participate in family activities/ responsibilities. }\end{array}$ & $\begin{array}{l}\text { Strain-based } \\
\text { WIF }\end{array}$ & .821 & .039 & .151 & .095 \\
\hline $\begin{array}{l}\text { I have to miss family activities due to the amount of time I must } \\
\text { spend on work responsibilities. }\end{array}$ & $\begin{array}{l}\text { Time-based } \\
\text { WIF }\end{array}$ & .795 & -.176 & .068 & .190 \\
\hline $\begin{array}{l}\text { The time I must devote to my job keeps me from participating } \\
\text { equally in household responsibilities and activities. }\end{array}$ & $\begin{array}{l}\text { Time-based } \\
\text { WIF }\end{array}$ & .783 & .009 & .053 & .019 \\
\hline $\begin{array}{l}\text { I am often so emotionally drained when I get home from work } \\
\text { that it prevents me from contributing to my family. }\end{array}$ & $\begin{array}{l}\text { Strain-based } \\
\text { WIF }\end{array}$ & .765 & .290 & .138 & .070 \\
\hline $\begin{array}{l}\text { Due to all the pressures at work, sometimes when I come home } \\
\text { I am too stressed to do the things I enjoy. }\end{array}$ & $\begin{array}{l}\text { Strain-based } \\
\text { WIF }\end{array}$ & .711 & .252 & .089 & -.050 \\
\hline $\begin{array}{l}\text { My work keeps me from my family activities more than I } \\
\text { would like. }\end{array}$ & $\begin{array}{l}\text { Time-based } \\
\text { WIF }\end{array}$ & .677 & -.023 & .056 & .008 \\
\hline $\begin{array}{l}\text { Because I am often stressed from family responsibilities, I have } \\
\text { a hard time concentrating on my work. }\end{array}$ & $\begin{array}{l}\text { Strain-based } \\
\text { FIW } \\
\end{array}$ & .077 & .856 & -.019 & .196 \\
\hline $\begin{array}{l}\text { Tension and anxiety from my family life often weakens my } \\
\text { ability to do my job. }\end{array}$ & $\begin{array}{l}\text { Strain-based } \\
\text { FIW }\end{array}$ & .067 & .788 & .105 & .232 \\
\hline $\begin{array}{l}\text { Due to stress at home, I am often preoccupied with family } \\
\text { matters at work. }\end{array}$ & $\begin{array}{l}\text { Strain-based } \\
\text { FIW } \\
\end{array}$ & .039 & .718 & .070 & .333 \\
\hline $\begin{array}{l}\text { Behavior that is effective and necessary for me at home would be } \\
\text { counterproductive at work. }\end{array}$ & $\begin{array}{c}\text { Behavior- } \\
\text { based } \\
\text { FIW }\end{array}$ & -.013 & .051 & .759 & .087 \\
\hline $\begin{array}{l}\text { The behaviors that work for me at home do not seem to be } \\
\text { effective at work. }\end{array}$ & $\begin{array}{l}\text { Behavior- } \\
\text { based FIW }\end{array}$ & .146 & .216 & .678 & -.100 \\
\hline $\begin{array}{l}\text { The problem-solving behaviors I use in my job are not effective in } \\
\text { resolving problems at home. }\end{array}$ & $\begin{array}{l}\text { Behavior- } \\
\text { based WIF }\end{array}$ & .043 & -.150 & .646 & .254 \\
\hline Behavior that is effective and necessary for me at work would be & Behavior- & .129 & -.111 & 642 & -.115 \\
\hline
\end{tabular}




\begin{tabular}{|c|c|c|c|c|c|}
\hline counterproductive at home. & based WIF & & & & \\
\hline $\begin{array}{l}\text { The problem-solving behavior that work for me at home does not } \\
\text { seem to be as useful at work. }\end{array}$ & $\begin{array}{l}\text { Behavior- } \\
\text { based FIW }\end{array}$ & .168 & .286 & .555 & .014 \\
\hline $\begin{array}{l}\text { The time I spend with my family often causes me not to spend } \\
\text { time in activities at work that could be helpful to my career. }\end{array}$ & $\begin{array}{c}\text { Time-based } \\
\text { FIW }\end{array}$ & -.018 & .195 & .108 & .810 \\
\hline $\begin{array}{l}\text { I have to miss work activities due to the amount of time I must } \\
\text { spend on family responsibilities. }\end{array}$ & $\begin{array}{c}\text { Time-based } \\
\text { FIW }\end{array}$ & .021 & .287 & .017 & .747 \\
\hline $\begin{array}{l}\text { The time I spend on family responsibilities often interfere with } \\
\text { my work responsibilities. }\end{array}$ & $\begin{array}{c}\text { Time-based } \\
\text { FIW }\end{array}$ & .276 & .221 & -.073 & .674 \\
\hline
\end{tabular}

NB: $\quad$ FIW denotes family interference with work WIF denotes work interference with family

\section{Criterion validity}

The criterion validity of the multi-dimensional WFC measure was explored by examining how the WFC dimensions identified through the PCA are correlated with other theoretically relevant variables. Table 5 shows the bivariate correlations between the WFC dimensions and various work and family variables included in the survey. Of the demographic variables, time- and strain-based WIF was significantly correlated with sex ( $\mathrm{r}=-$ $.209, \mathrm{p}=.011)$ and the number of children under 18 years old $(\mathrm{r}=-.179, \mathrm{p}=.030)$. Work-related correlates of time and strain-based WIF include hours worked each week $(r=.279, p=.001)$, supervisor support $(r=-.415, p=.000)$, perceptions of work=schedule fit $(\mathrm{r}=-.663, \mathrm{p}=.000)$, time adequacy $(\mathrm{r}=-.561, \mathrm{p}=.000)$, control $(\mathrm{r}=-.570, \mathrm{p}=.000)$ and flexibility $(\mathrm{r}=-.667, \mathrm{p}=.000)$. Time and strain-based WIF was also negatively correlated with family-to-work enrichment ( $\mathrm{r}=-.248, \mathrm{p}=.003)$ and work-to-family enrichment $(\mathrm{r}=-.290, \mathrm{p}=.000)$. Strain-based FIW was correlated with hours worked each week $(\mathrm{r}=-.199, \mathrm{p}=.016)$, supervisor support $(\mathrm{r}=-.208$ ' $\mathrm{p}=.013$ and family-towork enrichment ( $\mathrm{r}=-.263, \mathrm{p}=.002)$. Behaviour-based WIF and FIW (which emerged as a single factor in the PCA) was correlated with supervisory support $(r=-.180, p=.031)$, work-to-family enrichment $(r=-.307, p=.000)$ and time adequacy $(\mathrm{r}=-.191, \mathrm{p}=.022)$. Time-based FIW was only correlated with number of children under the age of $18(\mathrm{r}=-.222, \mathrm{p}=.007)$. 
Table 5: Bi-variate correlations between WFC and work and family variables

\begin{tabular}{|c|c|c|c|c|c|c|c|c|c|c|c|c|c|c|c|c|}
\hline & 1 & 2 & 3. & 4 & 5. & 6. & 7. & 8 & 9 & 10 & 11 & 12 & 13 & 14 & 15 & 16 \\
\hline 1. Age & 1 & $-.188^{*}$ & $-.254^{* *}$ & $-.600^{* *}$ & .014 & -.043 & -.147 & .008 & .126 & $.172^{*}$ & $.198^{*}$ & -.097 & .061 & $.221^{* *}$ & .073 & .162 \\
\hline 2. Sex & $-.188^{*}$ & 1 & .064 & -.001 & $-.235^{* *}$ & $-.209^{*}$ & .123 & .016 & -.090 & .087 & .128 & .112 & -.038 & .043 & .134 & .07 \\
\hline 3. Number of children & $-.254^{* *}$ & .064 & 1 & $.156^{*}$ & -.012 & $-.179^{*}$ & -.023 & -.105 & - & $.164^{*}$ & .071 & .118 & .064 & $.229^{* *}$ & $.229^{* *}$ & $.228^{*}$ \\
\hline$<18$ & & & & & & & & & $.222^{* *}$ & & & & & & & \\
\hline 4. Children 18 or over & $-.600^{* *}$ & -.001 & $.156^{*}$ & 1 & .093 & .065 & .030 & -.079 & -.054 & -.128 & -.143 & .061 & -.030 & -.128 & -.077 & -.158 \\
\hline $\begin{array}{l}\text { 5. Hours worked per } \\
\text { week }\end{array}$ & .014 & $-.235^{* *}$ & -.012 & .093 & 1 & $.279^{* *}$ & $-.199^{*}$ & .051 & -.082 & .004 & -.142 & -.083 & .016 & -.135 & $-.286^{* *}$ & $-.285^{*}$ \\
\hline $\begin{array}{l}\text { 6. Time \& strain- } \\
\text { based WIF }\end{array}$ & -.043 & $-.209^{*}$ & $-.179^{*}$ & .065 & $.279^{* *}$ & 1 & -.041 & .015 & -.002 & $-.415^{* *}$ & $-.663^{* *}$ & $-.248^{* *}$ & $-.290^{* *}$ & $-.561^{* *}$ & $-.570^{* *}$ & $-.667^{*}$ \\
\hline 7. Strain-based FIW & -.147 & .123 & -.023 & .030 & $-.199^{*}$ & -.041 & 1 & -.074 & -.005 & $-.208^{*}$ & -.020 & $-.263^{* *}$ & -.041 & .033 & -.006 & -.02 \\
\hline $\begin{array}{l}\text { 8. Behaviour-based } \\
\text { WIF \& FIW }\end{array}$ & .008 & .016 & -.105 & -.079 & .051 & .015 & -.074 & 1 & .029 & $-.180^{*}$ & -.107 & -.142 & $-.307^{* *}$ & $-.191^{*}$ & -.123 & -.11 \\
\hline 9. Time-based FIW & .126 & -.090 & $-.222^{* *}$ & -.054 & -.082 & -.002 & -.005 & .029 & 1 & -.108 & .086 & -.090 & .089 & -.044 & -.151 & -.03 \\
\hline $\begin{array}{l}\text { 10. Supervisory } \\
\text { support }\end{array}$ & $.172^{*}$ & .087 & $.164^{*}$ & -.128 & .004 & $-.415^{* *}$ & $-.208^{*}$ & $-.180^{*}$ & -.108 & 1 & $.332^{* *}$ & $.354^{* *}$ & $.311^{* *}$ & $.457^{* *}$ & $.466^{* *}$ & $.514^{*}$ \\
\hline 11. Work-schedule fit & $.198^{*}$ & .128 & .071 & -.143 & -.142 & $-.663^{* *}$ & -.020 & -.107 & .086 & $.332^{* *}$ & 1 & $.306^{* *}$ & $.404^{* *}$ & $.569^{* *}$ & $.430^{* *}$ & $.609^{*}$ \\
\hline $\begin{array}{l}\text { 12. Family-to-work } \\
\text { enrichment }\end{array}$ & -.097 & .112 & .118 & .061 & -.083 & $-.248^{* *}$ & $-.263^{* *}$ & -.142 & -.090 & $.354^{* *}$ & $.306^{* *}$ & 1 & $.264^{* *}$ & $.294^{* *}$ & $.252^{* *}$ & $.340^{*}$ \\
\hline $\begin{array}{l}\text { 13. Work-to-family } \\
\text { enrichment }\end{array}$ & .061 & -.038 & .064 & -.030 & .016 & $-.290^{* *}$ & -.041 & $-.307^{* *}$ & .089 & $.311^{* *}$ & $.404^{* *}$ & $.264^{* *}$ & 1 & $.373^{* *}$ & $.262^{* *}$ & $.348^{*}$ \\
\hline 14. Time adequacy & $.221^{* *}$ & .043 & $.229^{* *}$ & -.128 & -.135 & $-.561^{* *}$ & .033 & $-.191^{*}$ & -.044 & $.457^{* *}$ & $.569^{* *}$ & $.294^{* *}$ & $.373^{* *}$ & 1 & $.495^{* *}$ & $.592^{*}$ \\
\hline 15. Control & .073 & .134 & $.229^{* *}$ & -.077 & $-.286^{* *}$ & $-.570^{* *}$ & -.006 & -.123 & -.151 & $.466^{* *}$ & $.430^{* *}$ & $.252^{* *}$ & $.262^{* *}$ & $.495^{* *}$ & 1 & $.793^{*}$ \\
\hline 16. Flexibility & $.162^{*}$ & .070 & $.228^{* *}$ & $-.158^{*}$ & $-.285^{* *}$ & $-.667^{* *}$ & -.024 & -.115 & -.035 & $.514^{* *}$ & $.609^{* *}$ & $.340^{* *}$ & $.348^{* *}$ & $.592^{* *}$ & $.793^{* *}$ & 1 \\
\hline
\end{tabular}

\footnotetext{
** correlation is significant at the 0.01 level
}

* correlation is significant at the 0.05 level 
Figure 1 shows respondents' average levels of the four dimensions of WFC by respondents' sex. Male respondents reported significantly higher levels of time- and strain-based WIF than female respondents. The mean score for men was 3.13, while the mean score for women was $2.76(t=2.189, p=.038)$. Males and females did not report significantly different levels of strain-based FIW, behaviour-based WIF and FIW or time-based FIW.

Figure 1: WFC by sex

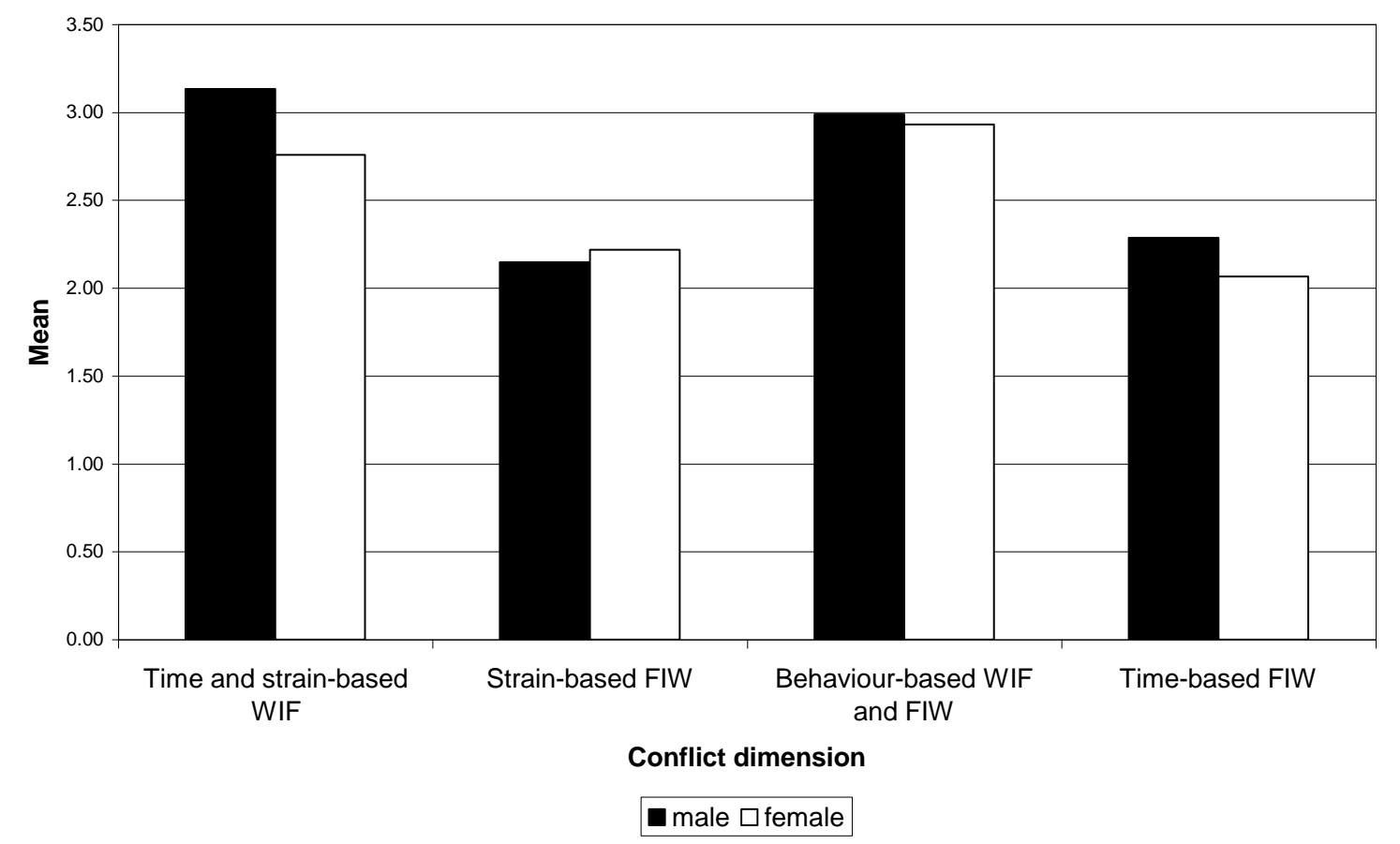

Figure 2 shows respondents' average levels of the four dimensions of WFC by their employment status (e.g. whether they are salaried or waged). Waged workers report significantly higher levels of time-and strain-based WIF (mean=3.21) than salaried workers (mean $=2.95 ; \mathrm{t}=-2.10, \mathrm{p}=.037$ ). Waged and salaried workers did not report significantly different levels of strain-based FIW, behaviour-based WIF and FIW or time-based FIW.

Figure 2: WFC by employment status 


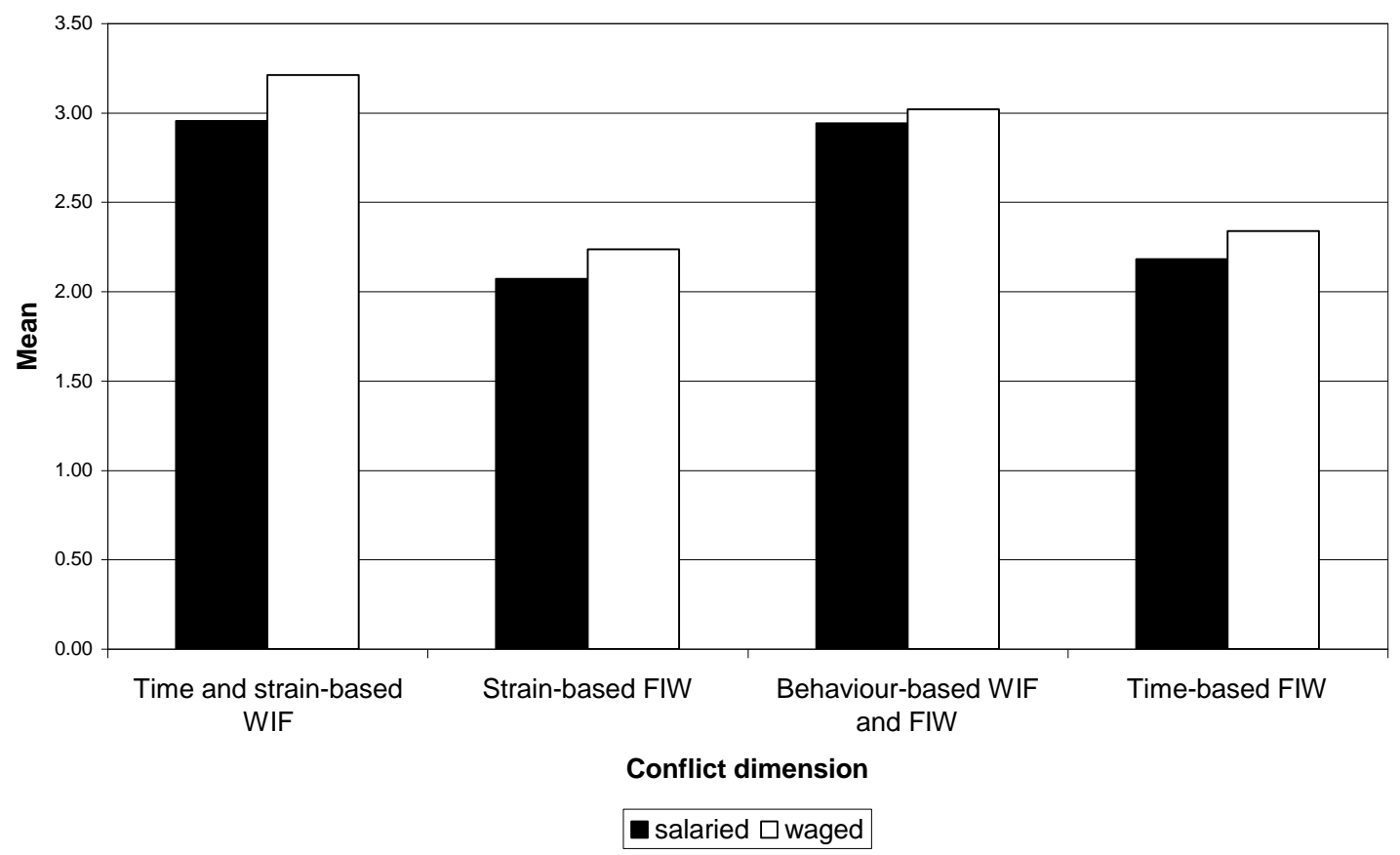

Figure 3 shows respondents' average levels of the four dimensions of WFC by their work location (e.g. whether they work predominantly in the site office or on-site engaged directly in construction work). Respondents who work on site in direct construction activity reported higher levels of all facets of work-family conflict than workers who work in the site office. However this difference was only statistically significant in the case of time- and strain-based WIF (F=5.652, $\mathrm{p}=.004)$.

Figure 3: WFC by work location

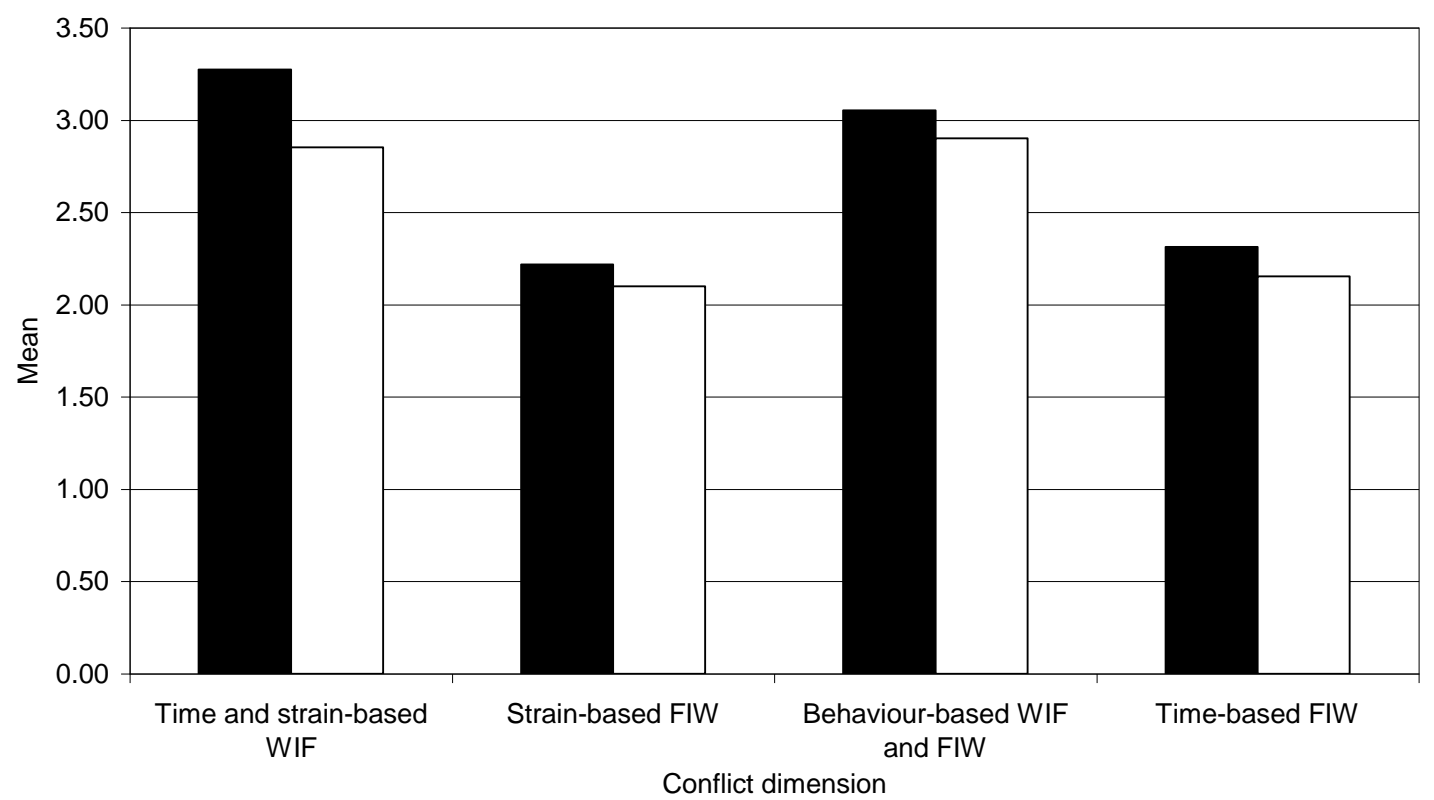

on site - direct construction activity $\square$ onsite - site office 
Figure 4 shows how respondents' average levels of the four WFC dimensions varied by age group. Workers in different age groups reported significantly different levels of time-based FIW, with workers aged 30 years or younger reporting significantly lower levels of this type of conflict $(\mathrm{F}=2.93, \mathrm{p}=.022)$.

Figure 4: WFC by age

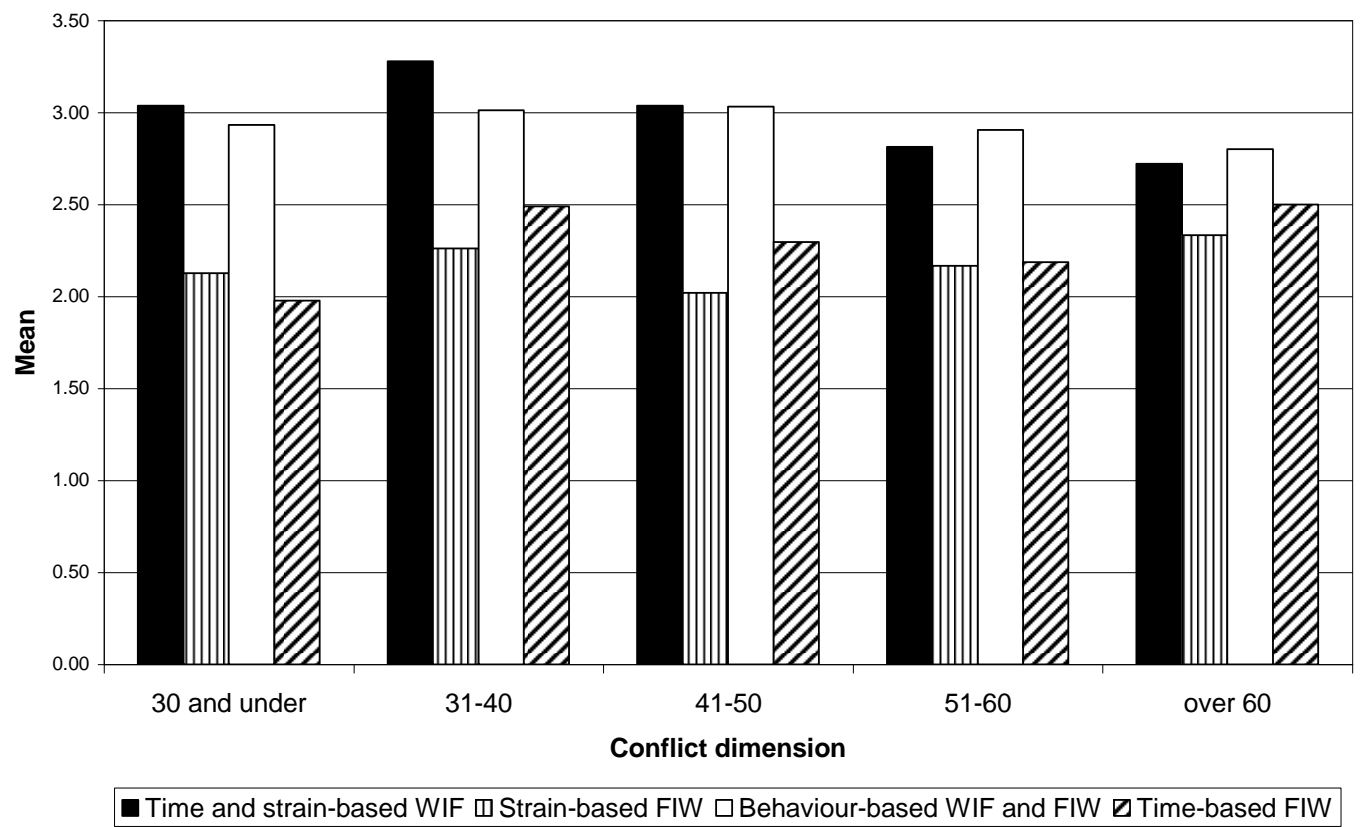

\section{Discussion}

The experience of WFC in construction

The average WIF conflict scores for the present sample of Australian construction workers were relatively high compared to the WFC levels reported in international studies that have used the WFC scale developed by Carlson et. al. (2000). Our results reveal important differences in the way that worker groups experience the WFC dimensions. The high levels of time- and strain-based WIF experienced by male workers, waged workers and workers engaged in site-based work in direct construction activity is of concern. The work-family experiences of these workers are not well understood, since most previous research has focused on white collar construction workers. Approximately half of the present sample was waged (rather than salaried) and, thus the findings shed new light on the magnitude of WFC in this group of workers. This is a cause of concern as research shows a strong and consistent linkage between WIF and workers' health and health-related behaviours (e.g. problem drinking, unhealthy eating habits and a lack of exercise). In Australia, comprehensive workforce health statistics are not routinely collected. However, a national telephone survey of 16,304 Australian workers conducted between 1998-2001 revealed that a large proportion of Australian workers rate their health to be suboptimal (Korda, Strazdins, Broom, \& Lim, 2002.). In this sample, male, blue-collar workers rated their health particularly poorly compared to other groups. These differences persisted after controlling for confounding variables including age, smoking and employment intensity (Korda et al. 2002). It is very important that the implications of high levels of WIF and opportunities for the mitigation of WIF in blue collar construction workers be the subject of future research. There is emerging evidence indicating that work-life strategies that are preferred by salaried (i.e. office based, managerial or professional) construction industry workers are not preferred by waged (i.e. blue collar) construction workers, especially as these relate to the adoption of alternative work schedules (Lingard, Townsend, Bradley \& Brown, 2008). While salaried workers prefer a reduction in weekly work hours and/or the elimination of Saturday work, these initiatives potentially reduce the weekly take-home pay of waged workers who are paid higher rates for hours worked above a weekly standard number of hours and work performed at the weekend. Given the significantly high levels of time- and strain- 
based WIF experienced by blue collar construction workers, it is imperative that future research examine in more detail the antecedents and consequences of WIF among this group in order to provide a greater depth of understanding upon which targeted work-family interventions can be developed.

\section{The structure of WFC}

Discriminant validity refers to the principle that indicators for different concepts should not be so highly correlated that 'conceptual overlap' is a problem. Where indicators intended to measure one concept are highly correlated with indicators intended to measure another concept, discriminant validity is low and it is concluded that the indicators do not discriminate between the two concepts, i.e. they measure the same thing. The PCA techniques used to analyse the WFC scores can help to ascertain the discriminant validity of the WFC subscales. The results of the PCA support the argument that WFC is a multi-dimensional construct but the six factor structure proposed by Carlson et al. (2000) was not replicated. Instead, a four factor structure emerged, indicating that respondents did not differentiate between time- and strain-based WIF. Also the PCA suggests that behaviour-based WFC is a uni-directional construct in that respondents failed to discriminate between behaviour-based WIF and FIW. The results of the PCA revealed that all of the survey questions, loaded very clearly on only one of the four factors. The clarity of the four factor solution suggests that the four WFC dimensions are conceptually different, indicating good discriminant validity. Given the relatively small sample used to conduct this analysis, it is important that the factor structure of the multi-dimensional WFC scale be further tested in future research in the construction industry.

\section{Criterion validity}

We assessed the criterion-related validity of the WFC scale by examining the bivariate correlations between the WFC dimensions that emerged from the PCA and a number of other work and family constructs theorized to be related to perceptions of WFC. Significant correlations between theoretically relevant variables and the construct of interest have been suggested to be an indication of the criterion-related validity of new constructs (Hinkin, 1998). In the present study, the additional measured variables were respondents' age, sex and the number of children they have, hours worked each week, supervisory support, perceptions of work-schedule fit, time adequacy, control and flexibility and work-to-family and family-to-work enrichment.

The number of children is a surrogate measure of demands in the family domain. The number of hours worked each week is a type of job demand and is indicative of an employee's objective workload. It was expected that hours worked would be positively correlated with WIF. It was expected that the number of children would be positively correlated with aspects of FIW. Work-schedule fit, time adequacy, control and flexibility are job characteristics that reflect the extent to which a person's job is able to provide a good fit with the fulfilment of requirements or expectations in non-work life (Moen et al. 2008). It was expected that these job characteristics would be negatively correlated with aspects of WIF. Supervisory support has also been identified as a significant direct predictor of lower levels of WIF (Seiger \& Weise, 2009) and was expected to be negatively correlated with WIF in the present study. Work-to-family and family-to work enrichment is defined as 'the extent to which experiences in one role improves the quality of life in the other role' (Greenhaus \& Powell, 2006, p.73). It was expected that work-family enrichment would be negatively correlated with WFC.

Consistent with expectations, work domain variables were strongly correlated with time-and strain-based WIF. Time- and strain-based WIF was positively correlated with hours worked per week and negatively correlated with perceptions of supervisor support, work-schedule fit, time adequacy, control and flexibility. Time- and strain-based WIF was also strongly correlated with work-to-family enrichment and family-to-work enrichment. These correlations were all strong and in the expected direction. Strain-based FIW was weakly correlated with supervisor support and moderately correlated with family-to-work enrichment. Both of these correlations were negative and therefore in the expected direction. Few significant correlations were found between behaviourbased work-family conflict and the other variables of theoretical relevance. Contrary to expectation the number of children under 18 was strongly negatively correlated with time-based FIW. This finding might be due to the 
fact that the sample comprised mainly of males who may be in 'traditional' family arrangements in which their female partners are not in paid employment or work only part time.

These results suggest a degree of criterion validity, especially in relation to time- and strain-based WIF. It is unsurprising that relatively few significant correlations were found between the dimensions of FIW and the variables included in the survey because (with the exception of the number of children) these were work domain variables. The domain specificity of antecedents of WFC in previous studies (Frone et al., 1997; Michel et al. 2009), would suggest that work domain variables would not be strong correlates of FIW. The fact that familyto-work enrichment but not work-to-family enrichment was negatively correlated with strain-based FIW does support the criterion validity of this WFC dimension.

\section{Conclusions}

The results have important implications for research and practice. They suggest WFC is best treated as a multidimensional construct because the four dimensions of WFC were correlated with other theoretically relevant work and family variables in different ways. Specifically, time and strain-based WIF was predicted by a number of work-related variables, including perceptions of work schedule 'fit', control and flexibility that did not predict other dimensions of WFC, while supervisory support was a significant predictor of time and strain-based WIF, strain-based FIW and behaviour-based WIF and FIW. Future research should adopt a more fine-grained approach to the measurement and analysis of WFC because understanding how the different dimensions of WFC are related to work and family circumstances can inform the development and evaluation of strategies and interventions to alleviate WFC. Our results reveal that the experience of the WFC dimensions varied by age, sex and employment arrangement (e.g. whether someone is waged or salaried). Waged workers suffered higher levels of time and strain-based WIF than salaried workers and employees under the age of 30 reported lower levels of FIW. The use of uni-dimensional WFC measures is likely to obscure important differences in the way in which worker groups in the construction industry experience WFC. The high levels of time- and strain-based WIF reported by the construction sample, relative to levels reported in other studies, highlight the magnitude of the problem. While our results are consistent with the findings of previous researchers who have found that workplace supports, such as supervisor support, flexibility and control, are important factors in alleviating WFC more research in the construction industry is required to examine the extent to which the WFC of different worker groups can be reduced through the provision of these types of support.

\section{Limitations and future research}

The research had some significant limitations. First, due to the fact that the sample for this analysis was drawn from a single, albeit large, construction project in Melbourne, it is not possible to generalize the findings to the population of construction workers in Australia. More research is needed using random sampling and larger sample sizes to determine to what extent the findings are generalizable. Second, the research provides limited information about the correlates of FIW, partly because few family-domain variables were included in the survey. This research was undertaken as a baseline survey in a larger research project in which work-family supports will be designed, implemented and evaluated in a number of case study construction projects. Thus, the focus was on the impact of workplace factors in shaping work-family experiences. Future research should investigate the relationship between family-domain variables, such as family time demands and family social support on FIW.

\section{Acknowledgement}

This research was funded by the Australian Research Council under Linkage Project Grant LP08820335. Grateful thanks are also extended to employees at the West Gate Freeway Alliance construction project.

\section{References}

Allen, T.D., Herst, D.E.L., Bruck, C.S. \& Sutton, M. (2000), Consequences associated with work-to-family conflict: a review and agenda for future research, Journal of Occupational Health Psychology, 5, 278-308. 
Beutell, N. J. \& Wittig-Berman, U., (2008), Work-family conflict and work-family synergy for generation X, baby boomers and matures, Journal of Managerial Psychology, 23, 507-523.

Boyar, S.L., Maertz, C.P. Jr, Pearson, A.W. \& Keough, S. (2003), Work-family conflict: a model of linkages between work and family domain variables and turnover intentions, Journal of Managerial Issues, 15, 175-90.

Boyar, S. L., Maertz, C. P. (Jr), Mosely, D. C. (Jr) \& Carr, J. C., (2008), The impact of work/family demand on work-family conflict, Journal of Managerial Psychology, 23, 215-235.

Bruck, C. S., Allen, T. D., \& Spector, P. E., (2002), The relation between work-family conflict and job satisfaction: A finer-grained analysis, Journal of Vocational Behavior, 60, 336-353.

Cardenas, R. A. \& Major, D. A., (2005), Combining Employment and Breastfeeding: Utilizing a Work-Family Conflict Framework to Understand Obstacles and Solutions, Journal of Business and Psychology, 20, 31-51

Carlson, D. S., Kacmar, K. M. \& Williams, L. J., (2000), Construction and Initial Validation of a Multidimensional Measure of Work-Family Conflict, Journal of Vocational Behavior, 56, 249-276.

Carlson, D. S., Brooklyn Derr, C. \& Wadsworth, L. L. (2003), The effects of internal career orientations on multiple dimensions of work-family conflict. Journal of Family and Economic Issues, 24, 99-116.

Carlson, D. S., Kacmar, K. M., Holliday Wayne, J. \& Grzywacz, J. G., (2006), Measuring the positive side of the work-family interface: Development and validation of a work-family enrichment scale, Journal of Vocational Behavior, 68, $131-164$.

Dierdorff, E. C. \& Ellington, J. K., (2008), It's the nature of the work: Examining behavior-based sources of work-family conflict across occupations, Journal of Applied Psychology, 93, 883-892.

Eby, L. T., Casper, W. J., Lockwood, A., Bordeaux, C. \& Brinley, A., (2005), Work and family research in IO/OB: Content analy sis and review of the literature (1980-2002). Journal of Vocational Behaviour, 66, 124-1197.

Ford, M. T., Heinen, B. A., \& Langkamar, K. L., (2007), Work and family satisfaction and conflict: A meta analysis of cross-domain relations, Journal of Applied Psychology, 92, 57-80.

Frone, M.R. (2000), Work-family conflict and employee psychiatric disorders: the national comorbidity survey, Journal of Applied Psychology, 85, 888-895.

Frone, M.R., Yardley, J.K. \& Markel, K.S. (1997), Developing and testing an integrative model of the work-family interface, Journal of Vocational Behavior, 50, 145-67.

Grant-Vallone, E.J. \& Donaldson, S.I. (2001), Consequences of work-family conflict on employee well-being over time, Work \& Stress, 15, 214-26.

Greenhaus, J. H. \& Beutell, N. J., (1985), Sources of Conflict Between Work and Family Roles, Academy of Management Review, 10, 76-88.

Greenhaus, J. H. \& Powell, G. N., (2006), When work and family are allies: A theory of work-family enrichment, Academy of Management Review, 31 (1), 72-92.

Grzywacz, J.G. \& Marks, N.F. (2000), Family, work, work-family spillover and problem-drinking during midlife, Journal of Marriage and the Family, 62, 336-48.

Grzywacz, J.G. \& Marks, N.F., (2000b). Reconceptualizing the work-family interface: An ecological perspective on the correlates of positive and negative spillover between work and family, Journal of Occupational Health Psychology, 5, 111 - 126.

Grzywacz, J. G. \& Butler, A. B., (2005), The impact of job characteristics on work-to-family facilitation: testing a theory and distinguishing a construct, Journal of Occupational Health Psychology, 10 (2), 97-109.

Hammer, T.H., Saksvik, P.Ø., Nytrø, K., Torvatn, H. \& Bayazit, M. (2004), Expanding the psychosocial work environment: workplace norms and work-family conflict as correlates of stress and health, Journal of Occupational Health Psychology, 9, 83-97.

Hanson, G. C., Hammer, L. B. \& Colton, C. L. (2006), Development and validation of a multidimensional scale of perceived workfamily positive spillover, Journal of Occupational Health Psychology, 11, 249-265.

Hill, E., Hawkins, A., Ferris, M., and Weitzman, M. (2001). Finding an extra day a week: The positive influence of perceived job flexibility on work and family life balance. Family Relations, 50, 49 - 58.

Hinkin, T. R., (1998), A brief tutorial on the development of measures for use in survey questionnaires. Organizational Research Methods, 1, 104-121.

Huang, Y.-H., L. B. Hammer, Neal, M. B. \& Perrin, N. A., (2004), The relationship between work-to-family conflict and family-towork conflict: A longitudinal study, Journal of Family and Economic Issues, 25, 79-100.

Hutchinson, A., \& Gallagher, J. (2003). Project alliances: an overview, Alchimie Pty Ltd and Phillips Fox Lawyers. First issued as the Centre of Advanced Engineering Seminars, Auckland and Christchurch, New Zealand, March 2003.

Innstrand, S. T., Langballe, E. M., Espnes, G. A., Falkum, E. \& Aasland, O. G., (2008), Positive and negative work-family interaction and burnout: A longitudinal study of reciprocal relations, Work \& Stress, 22, 1-15.

Janzen, B. L., N. Muhajarine, N. \& Kelly, I. W., (2007), Work-family conflict, and psychological distress in men and women among Canadian police officers, Psychological Reports, 100, 556-562.

Korda, R. J., Strazdins, L., Broom, D. H. \& Lim, L.. L-Y., (2002), The health of the Australian workforce: 1998-2001, Australian and New Zealand Journal of Public Health, 26, 325-331.

Lambert, S.J. (2000) Added benefits: The links between work-life benefits and organizational citizenship behavior. Academy of Management Journal, 43, 801 - 815.

Lingard, H. and Francis, V. (2004) A comparative study of the work-life experiences of men and women working in office and sitebased roles in the Australian construction industry. Construction Management and Economics, 22, 991-1002.

Lingard, H. \& Francis, V. (2006), Does a supportive work environment moderate the relationship between work-family conflict and burnout among construction professionals? Construction Management and Economics. 24: pp. 185-194. 
Lingard, H. \& Francis, V. (2005) Does work-family conflict mediate the relationship between job schedule demands and burnout in male construction professionals and managers? Construction Management and Economics. 23: pp. 733-745.

Lingard, H. \& Francis, V., (2007), Negative interference" between Australian construction professionals' work and family roles: Evidence of an asymmetrical relationship, Engineering, Construction and Architectural Management, 14, 79-93

Lingard, H., Townsend, K., Bradley, L. \& Brown, K., (2008), Alternative work schedules in the Australian construction industry: A comparative case study analysis. Construction Management and Economics, 26, 1101-1112.

Madsen, S. R. (2006), Work and family conflict: Can home-based teleworking make a difference?, International Journal of Organization Theory and Behavior, 9, 307-350.

Mauno, S., Kinnunen, U. \& Ruokolainen, M., (2006), Exploring work- and organization-based resources as moderators between work-family conflict, well-being and job attitudes, Work \& Stress, 20, 210-233.

Mesmer-Magnus, J. R. \& Viswesvaran, C., (2005), Convergence between measures of work-to-family and family-to-work conflict: A meta analytic examination, Journal of Vocational Behavior, 67, 2115-232.

Michel, J. S., Mitchelson, J. K., Kotrba, L. M., LeBreton, J. M. \& Baltes, B. B., (2009), A comparative test of work-family conflict models and critical examination of work-family linkages, Journal of Vocational Behavior, 74, 199-218.

Moen, P., Kelly, E. \& Huang, R., (2008), 'Fit' inside the work-family black box: An ecology of the life course, cycles of control reframing, Journal of Occupational and Organizational Psychology, 811, 411-433.

Netemeyer, R.G., Boles, J.S. and McMurrian, R. (1996), Development and validation of work-family conflict and family-work conflict scales. Journal of Applied Psychology, 81, 400-10.

O’Driscoll, M.P., Poelmans, S., Kalliath, T., Allen, T.D., Cooper, C.L. and Sanchez, J.L. (2003), Family-responsive interventions, perceived organizational and supervisor support, work-family conflict and psychological strain, International Journal of Stress Management, 10, 326-44.

Seiger, C. P. \& Wiese, B. S., (2009), Social support from work and family domains as an antecedent or moderator of work-family conflicts, Journal of Vocational Behavior, 75, 26-37.

Thomas, L.T. \& Ganster, D.C. (1995). Impact of family-supportive work variables on work-family conflict and strain: A control perspective. Journal of Applied Psychology, 80, 6 - 15.

Wayne, J. H., Musisca, N. \& Fleeson, W., (2004), Considering the role of personality in the work-family experience: Relationships of the Big Five to work-family conflict and facilitation, Journal of Vocational Behavior, 64, 108-130.

van Daalen, G., Willemsen, T. M. \& Sanders, K., (2006), Reducing work-family conflict through different sources of social support." Journal of Vocational Behavior 69, 462-476.

Voydanoff, P. (2005), Work demands and work-to-family and family-to-work conflict: Direct and indirect relationships, Journal of Family Issues, 26, 707-726. 